International Journal of Physical Sciences and Engineering
Available online at http://sciencescholar.us/journal/index.php/ijpse
Vol. 2 No. 2, August 2018, pages: $88 \sim 100$
e-ISSN : 2550-6943, p-ISSN : 2550-6951
https://doi.org/10.29332/ijpse.v2n2.170

\title{
Design, Construction, and Energy of Sustainable Solar Dryers in Jipijapa Canton
}

\author{
CrossMark

\begin{abstract}
Alfredo Cecilio Zambrano Rodriguez a , Maria Rodriguez Gamez ${ }^{\text {b }}$, Luis Garcia Faure ${ }^{\text {c }}$
\end{abstract} \\ Article history: Received 10 March 2018, Accepted in revised form 10 July 2018, Approved 15 August 2018, \\ Available online 18 August 2018

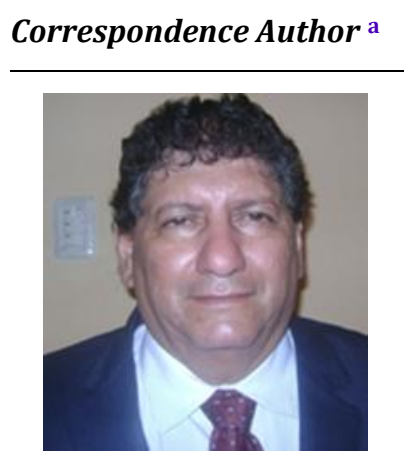 \\ Keywords \\ Coffee; \\ Construction; \\ Drying; \\ Local development; \\ Sustainable solar;

\begin{abstract}
Solar energy is one of the sources of renewable energy and more dispersed in the territory, this can be implemented for different energy uses for being a clean energy and that can be sustainable over time, the canton Jipijapa presents an annual radiation of $4.8 \mathrm{kWh} / \mathrm{m} 2$ day. In Cerro Grande community located in this area is located 529 meters above sea level, its inhabitants are engaged in agriculture, specifically the revival of the production of quality coffee for its taste and aroma. The drying treatment was not adequate, so their prices have dropped in the national and international market, with the aim of achieving a drying quality of this product and from knowing that the bamboo cane (Angustifolia Kunt) was a resource with good energy properties, two dryers were designed that take advantage of direct and indirect solar energy, to compare which was the most suitable for drying the coffee bean in a cleaner and simpler way. The results obtained in its design, construction and evolution determined that these types of drier can be implemented in communities that have the conditions of natural renewable resources and needs to improve the drying conditions of different agricultural products, thereby supporting the energetic and social sustainability of the populations that live in rural areas and that today are the base of the sustenance of agricultural products such as coffee,
\end{abstract} \\ cocoa, and others.
}

e-ISSN: 2550-6943, p-ISSN: 2550-6951 ๑Copyright 2018. The Author. SS Journals Published by Universidad Técnica de Manabí. This is an open-access article under the CC BY-SA 4.0 license (https://creativecommons.org/licenses/by-sa/4.0/) All rights reserved.

a Universidad Técnica de Manabí, FCMFQ, Career of Mechanical, Portoviejo, Manabí, Ecuador

b Universidad Técnica de Manabí, FCMFQ, Career of Electrical, FCMFQ, Career of Mechanical

c Universidad de Oriente, Energy efficiency center, Santiago de Cuba, Cuba 


\section{Contents}

Abstract

1. Introduction

2. Research Method

3. Results and Analysis

3.1 Characteristics of bamboo cane..

3.2 Drying alternatives

3.3 Monitoring of thermal variables in dryers .

4. Conclusion

Conflict of interest statement and funding sources.

Statement of authorship

Acknowledgements

References

\section{Introduction}

The drying process of coffee beans is an ancestral activity that is carried out in an impractical and hygienic way due to its high contact of the product with the bacteria present in the soil, even though in Ecuador this product is ancestral, not there is a reference about it.

In the canton Jipijapa the use of solar energy is almost zero, even with good solar radiation, this solar energy can be used to generate electricity using systems, solar collectors, for heating sanitary water, to operate cooling systems and refrigeration by absorption, as well as for the drying of fruits, grains, and spices.

In many rural places, we still practice the drying of grains, species or meats in the open air, which generates a rapid proliferation of microorganisms in the products that damage their quality and economic value, but in the Latin American region it is implemented in many countries solar drying, an example of this is Mexico with the drying of wood [1], chile [2]. Other countries such as Cuba, where solar drying is implemented for different products [3], including products such as algal biomass [4], in Colombia [5], in Peru have also experimented with the pineapple and plantain solar dryer [6]. A solar dryer has been built in Brazil in which drying trials of tropical fruits were carried out [7], in many places the work continues on the issue because of the need to achieve the conservation of agricultural products.

In Ecuador, due to climatic biodiversity and the conditions in different regions in which the country is divided, different experiences have been obtained regarding the evaluation and behavior of dryers for various uses [8].

The Cerro Grande site belonging to the canton Jipijapa presents good conditions for the cultivation of coffee beans, therefore it becomes a necessity the drying of products since when sold their price in the market rises when the grain is better dehydrated without affecting the properties of the grain in flavor and aroma.

Jipijapa is a well-known canton for its high production of coffee, so it is nationally known as "the Coffee Sultana" for its prosperous and traditional coffee production, which can be seen from Jipijapa to Cascol for the "Coffee Route" [9]

For many years, this canton has had great production and commercialization of this grain, in which a great variety of species can be found. In the parish of La América, the community of Cerro Grande is located, in which the inhabitants are dedicated especially to the planting and commercialization of coffee; finding different varieties that range from criollo coffee, Arara, catimor, among others [27].

Solar energy is the energy produced by the sun and converted to useful energy by humans, either to heat something or produce electricity (as its main applications) [10]. Every year the sun sheds 4 thousand times more energy than the one we consume, so its potential is practically unlimited. The intensity of energy available at a given point on the earth depends, on the day of the year, on the hour and on the latitude. In addition, the amount of energy that can be collected depends on the orientation of the receiving device [11].

It is currently one of the most developed and used renewable energies in the world, there are several ways to collect and exploit the sun's rays to generate energy that give rise to different types of solar energy: photovoltaic (which transforms the rays into electricity through the use of solar panels), thermal photo

Rodriguez, A. C. Z., Gamez, M. R., \& Faure, L. G. (2018). Design, construction, and energy of sustainable solar dryers in Jipijapa Canton. International Journal of Physical Sciences and Engineering, 2(2), 88-100. https://doi.org/10.29332/ijpse.v2n2.170 
(which uses heat through solar collectors) and thermoelectric (transforms heat into electrical energy indirectly). It has always been used in daily life and domestic work, but only in the nineteenth-century research began to apply a technology that would allow this energy to be used as a caloric and electric source on a commercial and massive scale [28].

According to the account, the famous Greek mathematician and scientist Archimedes (3rd century BC) would have used an ingenious way of defending his city, Syracuse, from the Roman siege: using concave mirrors he would have burned the enemy ships that besieged the city [12].

True or false history, illustrates the fact that the concentration of solar rays produces high temperatures. However, it was not until the 19th century that the first steps were taken to apply this principle to the industrial use of the solar heat source. The French engineer Auguste Mouchot created a system to convert solar radiation directly into mechanical work [13].

Almost a century later, in the 1950s, inventors of Bell Labs (Daryl Chapin, Calvin Fuller, and Gerald Pearson) [14] developed a solar cell efficient enough to generate electricity capable of powering electrical devices.

The geographical location of Ecuador makes it a rich country with respect to the solar resource, as it is located in the solar belt of the planet where the angle of incidence of solar radiation is practically perpendicular to the Ecuadorian surface throughout the year, which does not occur

in other countries of the planet where the angle of incidence of sunlight varies according to the seasons of the year [15]. This comparative advantage of Ecuador translates into the reception of a constant and greater amount of solar radiation that varies within the Ecuadorian territory due only to local climatological and geographic conditions (for example, height above sea level or presence of cloudiness) [16].

The first data of insolation recorded in Ecuador correspond to those taken from the meteorological stations of the National Institute of Meteorology and Hydrology (INAMHI), these records have information since 1962 of global insolation (Wh/m2/day) and heliophany which is the duration of the solar brightness that corresponds to direct solar radiation (h / day). This first attempt to determine the solar potential in Ecuador was limited by the technology of that time, of the 54 stations most had a discontinuity in the data of several months. However, this first study suggested the provinces of Esmeraldas, Guayas, Azuay, El Oro and Zamora Chinchipe as areas of great solar potential. When comparing the data of global insolation with those of heliophany there is a direct relationship between both, the determination of this relationship plus the information of the annual isohelias map of INAMHI allowed the development of a reference map on insolation in Ecuador. The study suggested as possible areas of high insolation to the provinces of Pichincha, Imbabura, Cañar, Chimborazo, Esmeraldas Manabí, Guayas, Galápagos and the Cariamanga sector to the north. Since August 2008, Ecuador has an Atlas of Solar Irradiation developed by the Corporation for Energy Research (CIE) for use and dissemination by the National Electricity Council, CONELEC. In the Solar Atlas, you can find geo-referenced data on global, diffuse and direct radiation in continental Ecuador, this document being an important tool for developing solar energy projects.

The CIE used the CRS (Climatological Solar Radiation Model) model, developed by the National Renewable Energy Laboratory - NREL of the United States. The CIE, after filtering the data of the CRS model, selected those corresponding to the Ecuadorian territory, exporting them to a database compatible with a Geographic Information System (GIS) [17].

The Atlas of Solar Radiation of Ecuador has 39 maps in printed and digital format with a resolution of 1 $\mathrm{Km} 2$ in addition to the respective query software and the corresponding database; it has direct, diffuse and global monthly radiation information and the annual averages in $\mathrm{Wh} / \mathrm{m} 2 /$ day. Having this information is a contribution at the moment of implementing technologically efficient production processes in sectors such as agriculture and industry that involve the use of solar energy for example in pumping systems, grain grinding, self-consumption, lighting, heat generation, regulation of temperatures, etc.; all this by means of clean energies and with conditions of strategic advantage for the country due to its geographical location. The Technical University of Manabí (UTM) is investigating issues related to energy efficiency and renewable energy sources and using the databases of the Wind and Solar Energy Resources Assessment Project (SWERA) [18] has developed the map of solar radiation in the province of Manabí [19].

The objective of the research is to show the results obtained in the design of a sector built with local materials in the Cerro Grande site of the Jipijapa district to be used in solar drying for grains and where products with quality drying have been obtained 


\section{Research Method}

For the study, the database related to the solar radiation atlas of Ecuador was analyzed, where the sites with the highest average radiation are found in the year and the province of Manabí (Pedernales) occupies one of the privileged sites [16]. The average global solar insolation levels are in the order of 4,575 $\mathrm{kWh} / \mathrm{m} 2$ day [20].

For the design and construction of the dryers, the guadua cane was used as it is a natural resource native to the area and because it has good energetic properties, these characteristics make it the ideal material; In addition, the sustainability of the devices that are design since they do not have to look for resources outside the territory for the construction of the dryer and can successfully replace the wood and other conventional materials relieving the pressure to the exploitation of natural forests [26].

For the design of the dryer was used in AutoCAD [21], in addition to making the necessary heat transfer calculations, to decide its construction, in addition to GPS, for geographical location, anemometers to measure the wind speed, thermographic gun, for Measure the temperature gradients and hygrometer for moisture analysis.

\section{Results and Analysis}

\subsection{Characteristics of bamboo cane}

For the design of the dryers with a bamboo cane, the material was characterized starting from the knowledge of the plantation. The cross-section of the cane differs in an outer zone of approximately $30 \%$ and an internal porous white zone of approximately $70 \%$. With the increase in height above the ground, the portion of the dense outer fibers in relation to the cross section is higher and thus the thin stems are better than the thick stems in relation to the cross-section.

Deformation. For long-term loads, expressed through relaxation and contraction, it will depend on the bond that may have. In the case of shrinkage, this depends on the normal stress and the shrinkage value and the elastic modulus of the mineralized wood. For short-term load, the module has to be:

$\mathrm{wq}<0=1 / 350$, where $w q$ is the force applied as the effect of a short load.

The specific weight is a necessary variable to evaluate the degree of compaction of the cane. It is expressed taking into account the ratio of the mass of a body and the mass of a volume equal to that of another referential substance or standard substance.

The thermal and elastic properties, as well as the thermal conductivity, were evaluated. The values that can be obtained, is given by a lambda value (l) between 0.30 and $0.75 \mathrm{~W} / \mathrm{Km}$ (Watt / Kelvin * meter). Being within the range of concrete and wood. This gives the arrangement to be used outdoors, as in the interior, but inside it is advisable to use in combination with another element due to its low resistance to diffusion of steam.

The durability has a minimum of approximately 50 years, depending on its location and the external conditions to which it is exposed, this durability being variable since in Japan there are constructions of more than 100 years [22].

This material has a considerable percentage of humidity, known as sap, which is the conductor of the plant's nutrients that are obtained from the soil, and are necessary for the growth of the cane. The bamboo cane shrinks with the loss of $11 \%$ moisture and expands when it increases, to reduce changes in size, it must be subjected to the drying process, approaching the moisture content it will have when it is in use, ie 10 and $15 \%$ [23]

It has a good balance humidity of $20 \%$ and easily acquires water, since it is a hygroscopic material, being easily exposed to the proliferation of fungi and other organisms that grow in aqueous medium, for example, fungi, such as green penicillium, malt, and others, which can be easily removed from the surface of the cane once dry [24].

Rodriguez, A. C. Z., Gamez, M. R., \& Faure, L. G. (2018). Design, construction, and energy of sustainable solar dryers in Jipijapa Canton. International Journal of Physical Sciences and Engineering, 2(2), 88-100.

https://doi.org/10.29332/ijpse.v2n2.170 


\subsection{Drying alternatives}

There are basically two alternatives for drying coffee: naturally, in the sun, or mechanically. It can also be carried out in a combined way, some stages of drying with one alternative and the others, with the other. If the drying is totally solar, you get the so-called sun-dried coffee; and if, on the contrary, it is completely mechanically dried, conventional coffee is obtained, if the processes are partial, qualities similar to the previous ones will be obtained, but none will be like sun-dried coffee.

There are different types of solar dryers used in coffee drying: indirect, direct, mixed, parabolic and greenhouse solar dryer.

For the design of the dryer, different techniques of air circulation in the dryers were reviewed, such as natural and forced convection. The thermal variables of the dryers being an essential part in the operation of the solar collector of air, usually the ambient temperature at different times, the radiation of the sun and the wind are those factors that intervene in the thermal variables that based on studies the main on es have been the air density, the specific heat of the air, the Reynolds number (Re) to characterize the movement of a fluid (laminar or turbulent) and the Nusselt number $(\mathrm{Nu})$ for the determination of the transfer of heat by convection.

The geometric characteristics of the dryers were taken into account, the most common measures used globally depending on their application and for a better work in the drying of grain indirectly. The drawers were selected as shown in figure 1, in (A) the shed and in (B) the drawers in the inner part, where the solar radiation heats the air from the collector that goes to the drying chamber, where it is the product.

(A)

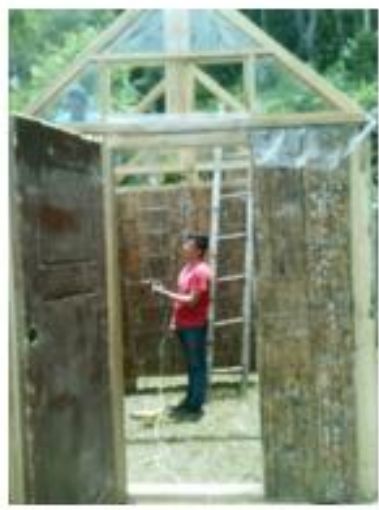

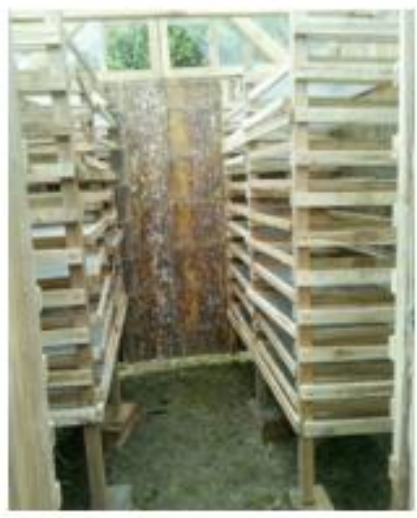

(B)

Figure 1. Solar drawer dryer

It was calculated heat transfer by varying the thickness of the walls to determine what is the optimal thickness of the insulation for the construction of the dryers by equation 1 , for different thicknesses $0.05,0.08$ and 0.10 meters.

$$
q^{\circ}=-k \frac{t 2-t 1}{L}
$$

Where:

$\mathrm{q}^{\circ} \rightarrow$ Calor

$\mathrm{k} \rightarrow$ Thermal conductivity of the insulator

$\mathrm{t} 1 \rightarrow$ room temperature ${ }^{\circ} \mathrm{K}$

t2 $\rightarrow$ interior temperature of the camera ${ }^{\circ} \mathrm{K}$

$\mathrm{L} \rightarrow$ thickness

Obtaining as a result that the losses of heat with a thickness of $10 \mathrm{~cm}$ are relatively admissible and will allow maintaining an optimum temperature of $60^{\circ} \mathrm{C}$ in the interior of the drying chamber. In the two types of 
dryers, insulating walls made of wood sawdust with a thickness of $10 \mathrm{~cm}$ will be used. Figure 2 (A) shows the structural design of the direct-radiating solar dryer and in (B), the design of the indirect solar radiation dryer with a 3-D view is shown.

These coffee dryers allow after their washing and draining of coffee to diminish its moisture content being a process that gives quality and added value to the product, since if it does not receive this drying it can be affected by over fermentation, fungi or microorganisms that damage irremediably the quality of the coffee; In addition, at the end of the drying process it can be stored to protect it from the environment and the climate, from sudden changes in temperature (always around $20 \mathrm{OC}$ ) and high temperatures that can create insects, odors, and pollution.
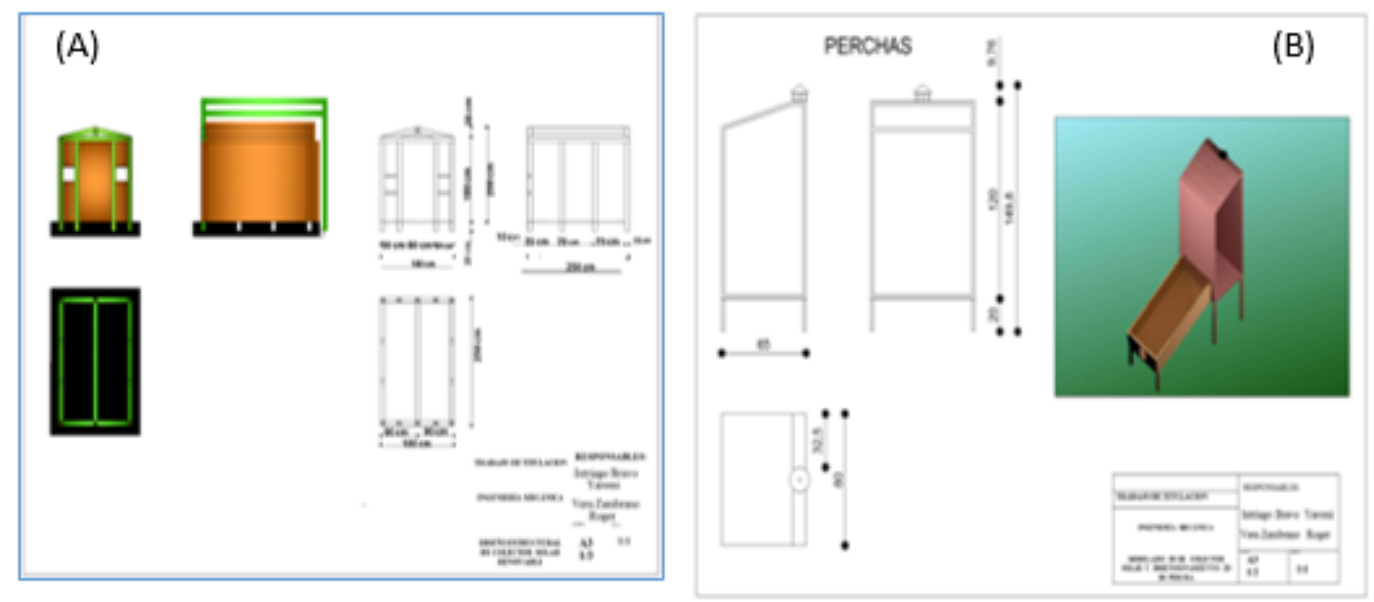

Figure 2. The structural design of the direct solar radiation dryer (A) and (B) indirect dryer

A polyethylene cover was used in one of the dryers because it is a very common plastic on the market and can replace the glass.

The energy analysis of the direct solar radiation dryer was done using equation 2 .

$$
S=\frac{Q p}{T}
$$

$\mathrm{S} \rightarrow$ Entropy $\left(\mathrm{KJ} /\left({ }^{\circ} \mathrm{k}\right)\right)$
$\mathrm{Qp} \rightarrow$ Heat Lost in $\mathrm{KJ}$
$\mathrm{T} \rightarrow$ Temperature in ${ }^{\circ} \mathrm{K}$

For the calculation of thickness transfer of the bamboo cane, equation (3) was used.

$$
q=\left(t_{2}-t_{1}\right) \frac{K}{e}
$$

Where:

$\mathrm{K} \rightarrow$ Thermal conductivity of bamboo cane $0.004 \mathrm{Kcal} / \mathrm{mh}^{\circ} \mathrm{C}$

$\mathrm{E} \rightarrow$ Thickness of bamboo cane $(1.5 \mathrm{~cm})$

(t_2-t_1) $\rightarrow$ Temperature differential $\left({ }^{\circ} \mathrm{C}\right)$

With these analyzes it was possible to perform the energy balance of the dryers, the following equation was used to determine the necessary parameters in each type of dryer.

For the calculation of the useful energy of the installation, it was obtained by means of equation 4 .

$$
\mathrm{Eu}=\mathrm{Qs}+\frac{\mathrm{Q}}{\mathrm{v}}
$$

Rodriguez, A. C. Z., Gamez, M. R., \& Faure, L. G. (2018). Design, construction, and energy of sustainable solar dryers in Jipijapa Canton. International Journal of Physical Sciences and Engineering, 2(2), 88-100. https://doi.org/10.29332/ijpse.v2n2.170 
Where:

Qs $\quad \rightarrow$ m_prod*cp (Tf-Ti)

mprod: $\rightarrow$ Mass of the product $(60 \mathrm{~kg})$

$\mathrm{Cp} \rightarrow$ Product specific heat $(0.85 \mathrm{kcal} / \mathrm{k} \mathrm{c})$

Tf $\rightarrow$ Maximum temperature of the product

$\mathrm{Ti} \rightarrow$ Temperature initial del Producto

The efficiency of the equipment was also calculated using the equation (5)

$$
\square=\frac{E u}{E i}
$$

Where:

$\mathrm{Ei} \rightarrow$ incident energy

The efficiency of the equipment for a load of $15 \mathrm{~kg}$ is $11.81 \%$, low level within the range established for natural convection without recirculation of air in dryers: from just under 10 to $35 \%$ in solar dryer's cabinet type in similar conditions [25].

\subsection{Monitoring of thermal variables in dryers}

Figure 3. shows how the temperature increases in both dryers as the hours of the day increase.

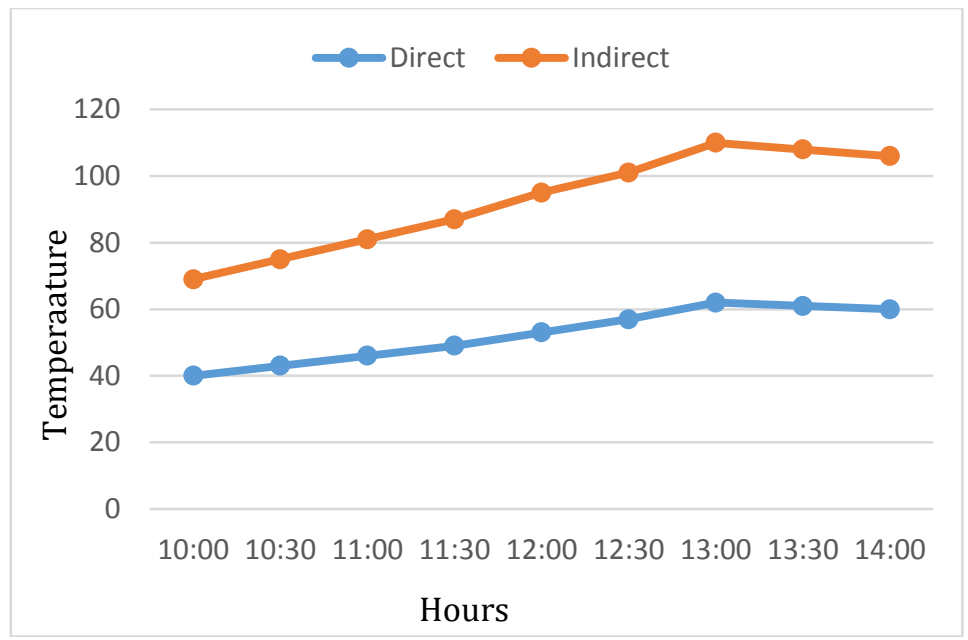

Figure 3. Heat transfer rate-room temperature

Figure 4 shows the values of heat transfer observed as the temperature increased this increases according to the type of dryer, for different thicknesses, noting that for the direct dryer its behavior is lower. 


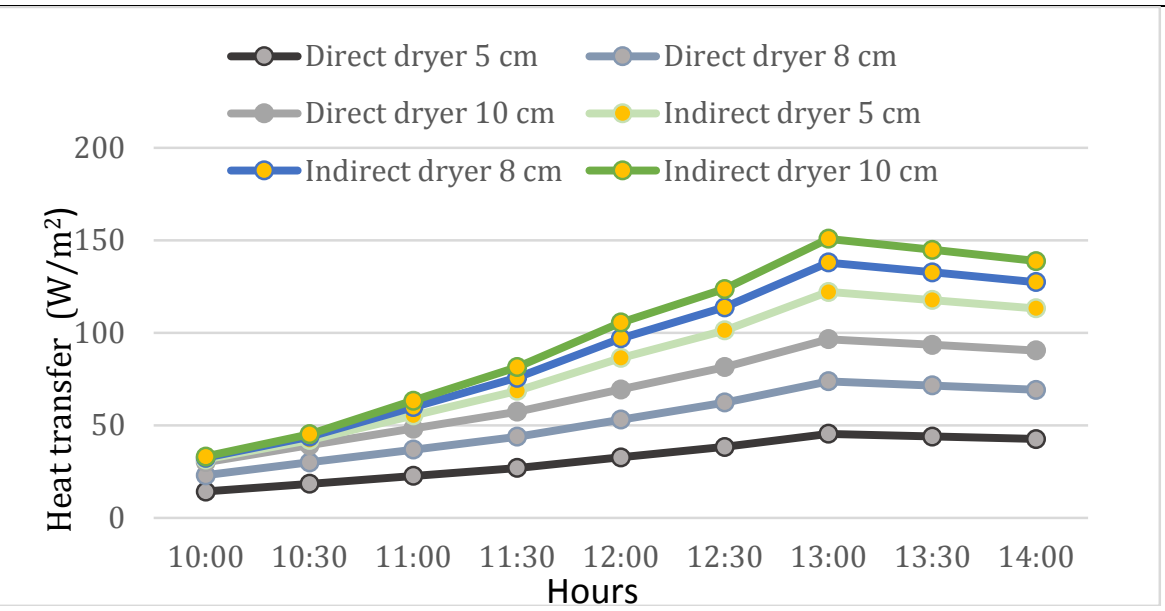

Figure 4. A heat transfer according to thickness and time of day

Figure 5 shows the performance of both dryers noticing that the direct dryer has a higher performance as the hours of the day increase.

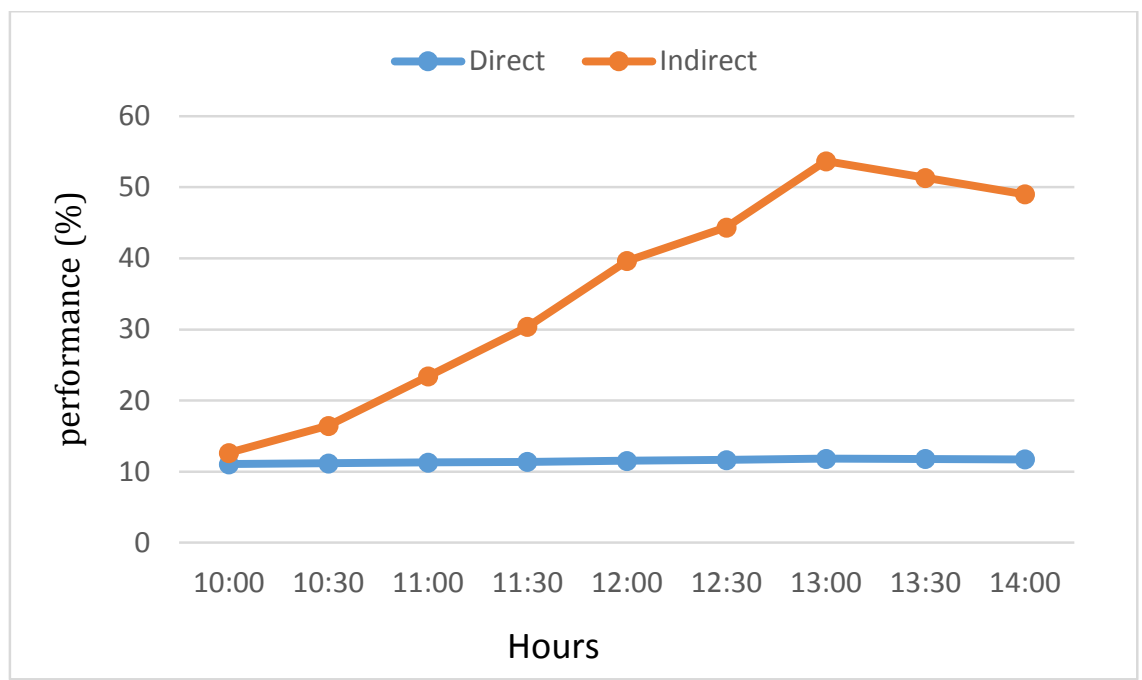

Figure 5. Performance of both dryers

In Figure 6, the entropy of the direct and indirect dryer is observed, noting that the indirect dryer has higher entropy.

Rodriguez, A. C. Z., Gamez, M. R., \& Faure, L. G. (2018). Design, construction, and energy of sustainable solar dryers in Jipijapa Canton. International Journal of Physical Sciences and Engineering, 2(2), 88-100. https://doi.org/10.29332/ijpse.v2n2.170 


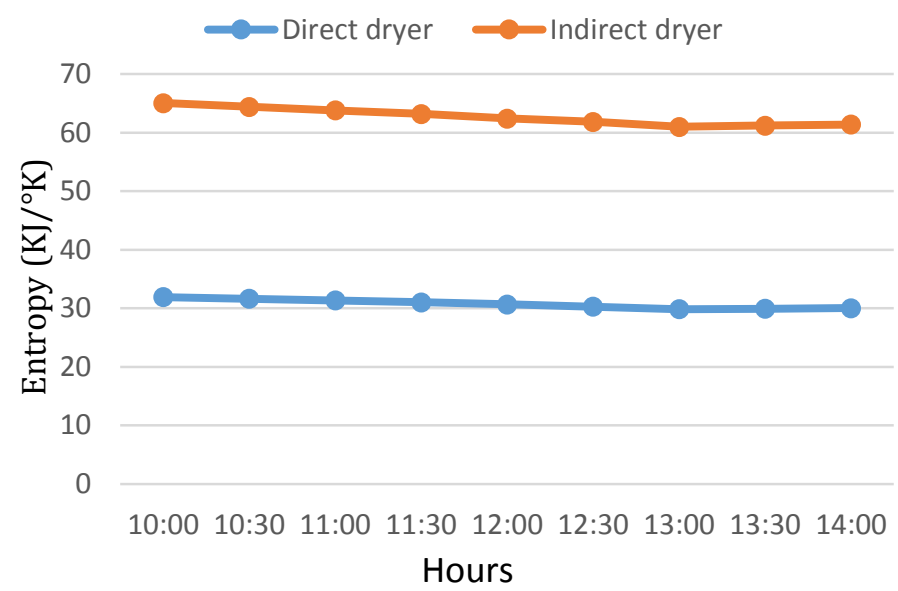

Figure 6. Entropy in direct and indirect drying

The results obtained have shown the technical feasibility of the construction of dryers with native resources of the area with this result is achieved that producers can dry their products in appropriate conditions providing quality to them.

The studies were carried out in order to determine the design and the materials to be used in the implementation of the two direct and indirect type solar dryers, it was possible to perform the energy analysis of the two models of solar dryers from the data obtained in the field with different measuring instruments.

This project serves as a contribution to the community, allowed the farmers to train themselves in how to take advantage of solar energy and in the construction of the dryers, these dryers provide the community with aid in the drying of coffee beans, cocoa and other seeds without losing their properties and improving their drying quality. It was determined that by means of the results and investigations carried out, the solar dryers with panels of bamboo cane and wood sawdust insulation, is a good ecological technique for the drying of grains. The trays designed and built for the drying of coffee beans are a tool of easy construction and low cost of maintenance.

\section{Conclusion}

The energy analysis of the two models of solar dryers was carried out from the data obtained in the field with different measuring instruments, checking the results of the bamboo cane for construction of dryers in isolated areas where it is expensive to move other materials. The result serves as an economic, social and environmental contribution for the community because it offers sustainable solutions taking advantage of the indigenous resources such as the materials of the construction of the device and the use of solar energy; It also allows improving the drying quality of different products in the isolated areas of Ecuador and can be generalized in sites with similar characteristics..

\section{Conflict of interest statement and funding sources}

This study was funded by the tutor and students linked to the project.

\section{Statement of authorship}

The authors have a responsibility for the conception and design of the study. The authors have approved the final article.

\section{Acknowledgments}

There is a special thank you to students who were working early in this investigation, Intriago Bravo Yaromi Oriana, and Vera Zambrano Roger Andrés. 


\section{References}

1. (IICA), I.I.d.C.p.l.A. (2008). Turismo rural en Ecuador,» IICA, pp. 1-45.

View in (PDF)

2. Andión-Torres, R., Suárez-Rodríguez, J. A., \& Bergues-Ricardo, C. C. (2012). Evaluación experimental de un secador solar tipo Gabinete para el secado de hollejo de naranja. Tecnología Química, 32(2), 223-233.

View in (Google Scholar)

3. AutoCAD. (2013). AutoCAD: 5 alternativas libres y gratuitas - Hipertextual.

View in (Website)

4. Bergues-Ricardo, C. C., Bérriz-Pérez, L., \& Griñán-Villafañe, P. (2013). Secadores solares directos: Una experiencia para su extensión y generalización en la zona oriental de Cuba. Tecnología Química, 33(1), 3140.

View in (Google Scholar)

5. Camarillo, H.I.G. (2014). Diseño y construcción de un prototipo de Sistema de control para helióstatos de torre Central.

View in (PDF)

6. Rodríguez Romo, J. C. (2006). El bambú como material de construcción. Conciencia Tecnológica, (31). View in (Google Scholar)

7. CONELEC. (2008). Atlas solar del ecuador con fines de generación eléctrica. p. 51.

View in (PDF)

8. Costa, A. R., \& Ferreira, S. R. (2007). Sistema de secado solar para frutos tropicales. Información tecnológica, 18(5), 49-58.

View in (Google Scholar)

9. Haro-Velasteguí, R.S.-M., Y. Llosas-Albuerne, R. Haber-. Guerra, G. Zavala-Sánchez. (2016). Simulación predictiva del funcionamiento de un secador solar usando la teoría del caos. p. 14.

View in (Article)

10. Rodríguez Murcia, H. (2008). Desarrollo de la energía solar en Colombia y sus perspectivas. Revista de ingeniería, (28).

View in (Google Scholar)

11. Ideenergía. (2016. Historia de la energía solar térmica I.

View in (Article)

12.Jiménez, Y.C.-D.L.A.-A.J. (1989). Un modelo para estimaciones climatológicas de radiación solar global, difusa y directa sobre una superficie horizontal. 42(5): p. 417-424.

View in (PDF), (Website)

13. Quintanar Olguín, J., Fuentes López, M. E., \& Tamarit Urías, J. C. (2011). Evaluación económica de un secador solar para madera. Revista mexicana de ciencias forestales, 2(7), 97-104.

View in (Google Scholar)

14. Méndez Cruz, J. I., \& Palominos Rizzo, M. T. (2005). Curado y preservación de la caña guadúa seleccionando agentes y preservantes químicos (Bachelor's thesis, Universidad de Guayaquil. Facultad de Ingeniería Química).

View in (Google Scholar)

Rodriguez, A. C. Z., Gamez, M. R., \& Faure, L. G. (2018). Design, construction, and energy of sustainable solar dryers in Jipijapa Canton. International Journal of Physical Sciences and Engineering, 2(2), 88-100.

https://doi.org/10.29332/ijpse.v2n2.170 
15. Myers, D. R. (2005). Solar radiation modeling and measurements for renewable energy applications: data and model quality. Energy, 30(9), 1517-1531.

View in (Google Scholar)

16. Dahbura Ramos, J. C. (2014). Evaluación del potencial de sustitución de energía de origen convencional por energías de origen renovable en planta productora de detergentes en polvo mediante el proceso de secado por pulverizado en municipio de San Salvador (Doctoral dissertation).

View in (Google Scholar)

17. Pelaez, J. (2013). El rayo de Arquímedes: De Siracusa a los Cazamitos.

View in (Article)

18. Perlin, J., de Linares, V. M. G. G., \& Santamarta, J. (1999). Historia de los bosques: el significado de la madera en el desarrollo de la civilización. Gaia.

View in (Google Scholar)

19. R; J.H., et al. (2010). Secado de chile habanero con energía solar. Revista Iberoamericana de Tecnología Postcosecha. ISSN (Versión impresa): 1665-0204.

View in (Website)

20. Roche-Delgado, L., Hernández-Touset, J. P., \& García-Rodríguez, A. (2017). Diseño conceptual de secador solar a escala piloto para algas marinas. Tecnología Química, 37(2), 184-200.

View in (Google Scholar)

21. Sarmiento Sera, A., Rodríguez Gámez, M., Castillo Castillo, O., \& Vázquez Pérez, A. (2014). Sistemas Integrados de energías con fuentes renovables, requisitos y opciones. Ingeniería Energética, 35(1), 70-78.

View in (Google Scholar)

22. SMA. (2013). Las regiones emergentes del cinturón solar de la Tierra son atractivas para grandes proyectos fotovoltaicos.

View in (Article)

23. Sabroso, V., \& Alberto, C. (2016). Diseño de secador solar de piña y plátano automático.

View in (Google Scholar)

24.Pérez, A. V., Arauz, W. M. S., Gámez, M. R., Fernández, M. C., \& Castro, V. H. N. (2017). Sistemas de información geográfica y microrredes. Revista Cubana de Ingeniería, 8(1), 24-29.

View in (Google Scholar)

25. Arauz, W., Gámez, M., Pérez, A., \& Fernández, M. (2016). Microgrids Views from a Geographic Information System. International Research Journal Of Engineering, IT \& Scientific Research (IRJEIS), 2(11), 51 - 57. doi:10.21744/irjeis.v2i11.308

View in (Google Scholar)

26. Santosa, I. G., \& Yusuf, M. (2017). The Application of a Dryer Solar Energy Hybrid to Decrease Workload and Increase Dodol Production in Bali. International Research Journal of Engineering, IT and Scientific Research (IRJEIS), 3(6), 95-101.

View in (Google Scholar)

27. Noa, A. P., Perez, A. V., Hechavarría, J. M., \& Santos, R. D. (2018). Energy interpretation of solar radiation affects for Artemisa province. International Journal of Physical Sciences and Engineering, 2(2), 39-49.

View in (Google Scholar) 
28. Chilán, J. C. H., Torres, S. G. P., Machuca, B. I. F., Cordova, A. J. T., Pérez, C. A. M., \& Gámez, M. R. (2018). Social Impact of Renewable Energy Sources in the Province of Loja. International Journal of Physical Sciences and Engineering (IJPSE), 2(1), 13-25.

View in (Google Scholar)

Rodriguez, A. C. Z., Gamez, M. R., \& Faure, L. G. (2018). Design, construction, and energy of sustainable solar dryers in Jipijapa Canton. International Journal of Physical Sciences and Engineering, 2(2), 88-100. https://doi.org/10.29332/ijpse.v2n2.170 


\section{Biography of Authors}

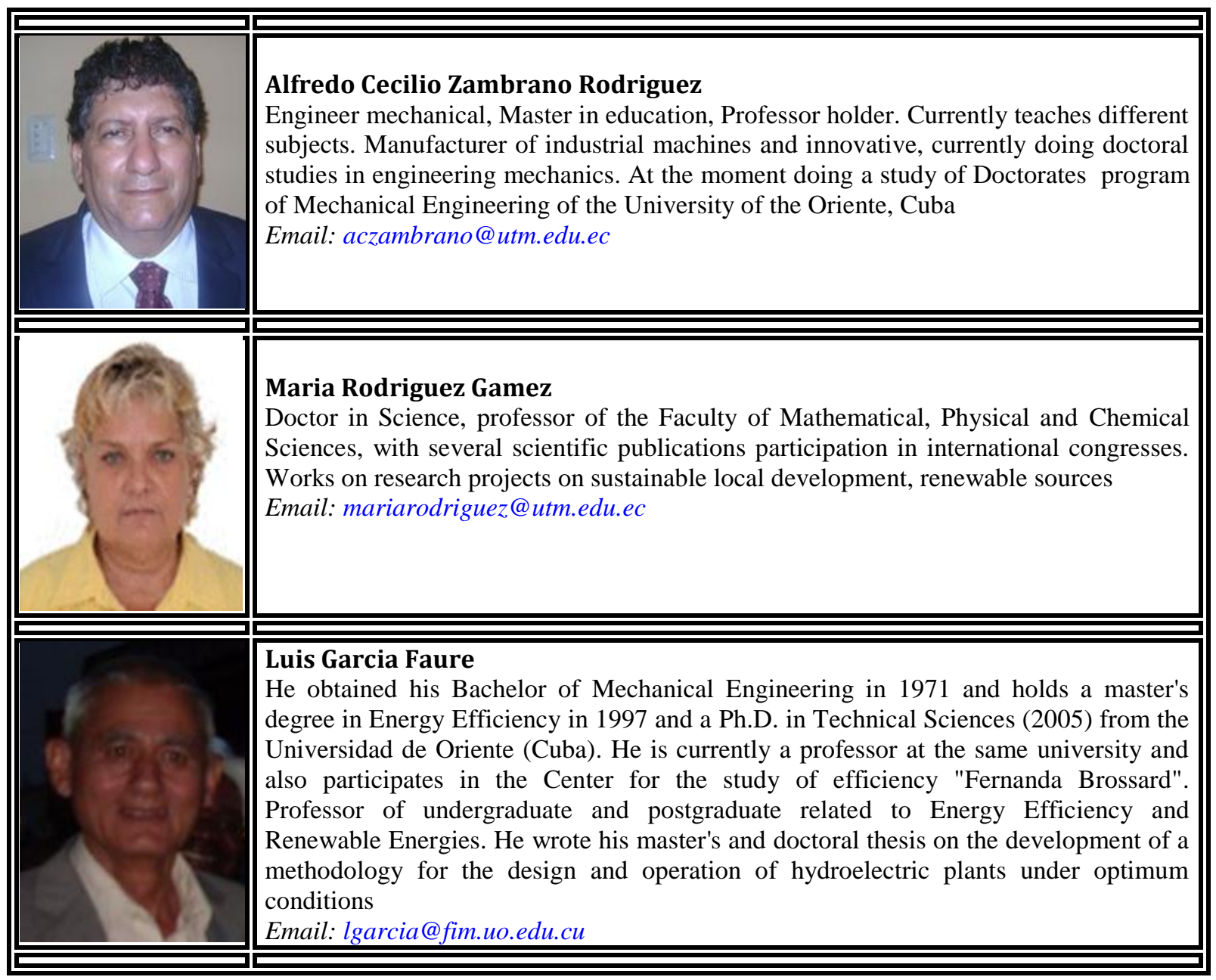

